Vol. 16 No. 2, Desember 2019

\title{
ISLAM PROGRESIF: TELAAH ATAS PEMIKIRAN OMID SAFI
}

\author{
Aminudin $^{1}$ \\ ${ }^{1}$ IAIN Sultan Amai Gorontalo, aminudin@iaingorontalo.ac.id
}

\begin{abstract}
This research is a research library by collecting primary and secondary data. This research will reveal the ideas of contemporary Islamic thought about Progressive Islam initiated by Omid Safi and his contribution to the treasures of contemporary Islamic thought. The ideas promoted by Progressive Islam, one of the trends of Islamic thought, to realize social justice, gender justice and pluralism are ideas that must awaken our humanity as part of human beings around the world originating from Prophet Adam As. Regardless of background, ethnicity, religion, gender and race, progressive Muslims must fight against all the injustices that exist around us. Not only do they criticize the injustices committed by Muslims themselves but also dare to criticize the injustices committed by West. Here the importance of multiple-criticism initiated by progressive Islam is.
\end{abstract}

\section{Keywords: Progressive Islam, Thought, Omid Safi}

\begin{abstract}
Abstrak: Penelitian ini merupakan library research dengan mengumpulkan data-data baik primer maupun sekunder. Penelitian ini akan mengungkap gagasan pemikiran Islam kontemporer tentang Islam Progresif yang di gagas oleh Omid Safi dan kontribusinya terhadap khazanah pemikiran Islam Kontemporer. Gagasan yang diusung oleh Islam Progresif, salah satu trend pemikiran Islam, untuk mewujudkan keadilan sosial, keadilan gender, dan pluralisme menjadi gagasan yang harus menggugah kemanusiaan kita sebagai bagian dari umat manusia di seluruh dunia yang berasal dari Nabi Adam As. Tanpa membedakan latar belakang, suku, agama, jenis kelamin dan ras, muslim progresif harus melawan semua ketidakadilan yang ada disekitar kita. Tidak hanya melakukan kritik terhadap ketidakadilan yang dilakukan umat Islam sendiri tapi juga berani mengkritik ketidakadilan yang dilakukan Barat. Disini pentingnya Multiple-kritik yang digagas oleh Islam progresif.
\end{abstract}

Kata kunci: Islam Progresif, Pemikiran, Omid Safi 


\section{FARABI}

Jurnal Pemikiran Konstruktif Bidang Filsafat dan Dakwah

ISSN $1907-0993$

E ISSN $2442-8264$

Vol. 16 No. 2, Desember 2019

\section{A. PENDAHULUAN}

Dewasa ini, pelabelan terhadap kelompok gerakan ke-Islaman semakin marak dan beragam seperti Islam Progresif misalnya, meskipun substansinya tidak jauh berbeda dengan terma-terma lain, seperti "Islam Inklusif", "Islam Transformatif", "Islam Berkemajuan", "Islam Nusantara" dan "Islam Liberal". Istilah "Islam Progresif" (Progressive Islam) merupakan istilah baru dalam kajian Islam kontemporer yang digunakan oleh para akademisi dan aktivis sejak beberapa tahun ini untuk memberikan label kepada pemahaman-pemahaman dan aksi-aksi umat Islam yang memperjuangkan penegakan nilai-nilai humanis, seperti pengembangan civil society, demokrasi, keadilan, kesetaraan jender, pembelaan terhadap kaum tertindas dan pluralisme. Di satu sisi pandangan dan aksi Islam Progresif, menurut Omid Safi, merupakan kelanjutan dan kepanjangan dari gerakan Islam Liberal yang muncul sejak kurang lebih seratus lima puluh tahun yang lalu. Namun, di sisi lain ia muncul sebagai bentuk ungkapan ketidakpuasan terhadap gerakan Islam Liberal yang lebih menekankan pada kitikkritik internal terhadap pandangan dan prilaku umat Islam yang tidak atau kurang sesuai dengan nilai-nilai humanis. Sementara itu, kritik terhadap modernitas, kolonialisme dan imperialisme justru tidak mendapatkan perhatian yang cukup dari gerakan Islam Liberal. ${ }^{1}$

Adalah Omid Safi orang yang memunculkan istilah Islam progresif sekaligus penulis ketika memberikan pengantar dan mengedit sebuah buku yang berjudul Progressive Muslim, tahun 2004. Muslim progresif juga dilabelkan Safi kepada para pemikir agama yang selama ini belum banyak memberikan uraian tentang bagaimana memaknai agama Islam di era kontemporer di tengah-tengah multi-religius dan multi-kultural.

Dalam pandangan dan aksi Islam Progresif, menurut Omid Safi merupakan kelanjutan dan kepanjangan dari gerakan Islam Liberal yang muncul sejak kurang lebih seratus lima puluh tahun yang lalu. Namun, di sisi lain ia muncul sebagai

\footnotetext{
${ }^{1}$ Omid Safi, "What is Progressive Islam," dalam The International Institute for the Study of Islam in the Modern World (ISIM) News Letter, No.13, Desember 2003.
} 


\section{FARABI}

Jurnal Pemikiran Konstruktif Bidang Filsafat dan Dakwah

ISSN $1907-0993$

E ISSN $2442-8264$

Vol. 16 No. 2, Desember 2019

bentuk ungkapan ketidakpuasan terhadap gerakan Islam Liberal yang lebih menekankan pada kitik-kritik internal terhadap pandangan dan prilaku umat Islam yang tidak atau kurang sesuai dengan nilai-nilai humanis. Sementara itu, kiritik terhadap modernitas, kolonialisme dan imprialisme justru tidak mendapatkan perhatian yang cukup dari gerakan Islam Liberal. ${ }^{2}$

Kenyataan inilah yang memberikan inspirasi terhadap munculnya pemahaman dan aksi Islam Progresif, yang memberikan perhatian yang seimbang antara kritik internal dan kritik eksternal. Kritik internal terhadap tradisi pemikiran sebagian umat Islam yang tidak menitikberatkan pada aspek-aspek kehidupan humanis memposisikan gerakan Islam Progresif pada gerakan modernis, namun pada waktu yang bersamaan ia juga merupakan gerakan "postmodernis", karena ia juga bersikap kritis terhadap modernitas yang bertentangan dengan nilai-nilai keadilan sejati dan kemanusiaan. Cara pandang, kritis dan aksi Islam Progresif semuanya hendaknya berorientasi kepada kemajuan. Atas dasar inilah ia disebut dengan istilah 'progresif' .

Penelitian ini membahas secara singkat inti permasalahan dalam perkembangan pemikiran dan gagasan muslim progresif. Pandangan dan aksi humanis tentunya bukan barang baru di Dunia Islam. Sejarah Islam memberikan informasi yang jelas bahwa Islam diturunkan ke bumi pada abad ke-7 M. dengan membawa misi-misi kemanusiaan, seperti perhatiannya terhadap hak-hak kaum wanita, penghapusan praktek perbudakan secara bertahap dan perhatian terhadap kaum lemah. Diwahyukannya Q.S. 4:11 merupakan salah satu contoh bahwa Islam memperhatikan dan menjunjung tinggi hak kaum wanita. Di dalam ayat ini Allah memerintahkan agar anak perempuan seperti halnya anak laki-laki diberi hak menerima harta warisan pada saat bangsa Arab saat itu konon tidak memberi wanita hak warisan sama sekali, bahkan menurut sebagian riwayat wanita justru diwariskan seperti harta benda. Sejarah juga menceritakan bahwa Nabi Muhammad Saw. memberikan kebebasan kepada kaum Nasrani dan Yahudi di Madinah untuk menjalankan ibadah sesuai dengan keyakinan keagamaan mereka

\footnotetext{
${ }^{2}$ Omid Safi (ed), Progresive Muslims; On Justice Gender and Pluralism (Oxford, 2005), hlm. 1.

${ }^{3}$ Farish A. Noor, Islam Progresif: Peluang, Tantangan, das Masa Depannya di Asia Tenggara, terj. Moch. Nur Ichwan dan Imron Rosyadi (Yogyakarta: SAMHA, 2006), hlm. 23.
} 


\section{FARABI}

Jurnal Pemikiran Konstruktif Bidang Filsafat dan Dakwah

ISSN $1907-0993$

E ISSN $2442-8264$

Vol. 16 No. 2, Desember 2019

dan hidup bersama secara damai dengan umat Islam pada waktu itu. Konon 'Umar ibn al-Khat\}t\}a>b melepaskan seorang pencuri tanpa diberi hukuman apapun ketika 'Umar mengetahui bahwa dia mencuri sesuatu dalam keadaan terpaksa. Sikap Umar dapat dipandang sebagai tindakan humanis progresif. Teori kemaslahatan yang dikembangkan oleh ulama ushul fiqh sebagai salah satu pertimbangan dalam memutuskan suatu hukum dan teori perubahan hukum atas dasar perubahan situasi dan kondisi juga membuka progresivitas hukum Islam. ${ }^{4}$

\section{B. PENGERTIAN ISLAM PROGRESIF}

Istilah Progressive Muslim ini dimunculkan oleh Omid $\mathrm{Safi}^{5}$ ketika memberikan pengantar dan mengedit sebuah buku yang berjudul Progressive Muslim, tahun 2004. Omid Safi berargumen bahwa dalam perkembangannya di Negara-negara berpenduduk muslim yang cukup banyak akan berkembang tradisi keislaman yang secara serius memperbincangkan masalah-masalah kemanusiaan seperti kemiskinan, demokrasi, kesetaraan, keadilan dan HAM. Masalah-masalah seperti itu merupakan masalah kontemporer yang pada perdebatan kaum muslim sebelum abad ke-20 jarang diperdebatkan secara serius. Namun sejak abad ke-20 sampai seterusnya akan mendapatkan perhatian serius sebab masalah-masalah itu merupakan masalah riil bukan saja menyangkut warga non muslim tetapi sekaligus masalah warga negara yang beragama Islam dalam sebuah Negara.

Istilah“Islam Progresif” yang merupakan pengembangan lebih mendalam dari pemikiran dan posisi "Islam moderat" sering dihadapkan dengan "Islam radikal" di satu sisi, dan "Islam Liberal" yang jauh lebih " sekuler" di sisi yang lain. Tetapi walaupun demikian antara pemikiran Islam Progresif dan Islam liberal

\footnotetext{
${ }^{4}$ Lihat Yudian Wahyudi, Maqashid Syari'ah dalam Pergumulan Politik (Yogyakarta: Nawesea, 2006).

${ }^{5}$ Omid Safi adalah Profesor Studi Agama, Universitas North Carolina di Chapel Hill. Dia adalah anggota Komite Pengarah untuk Studi Islam di American Academy of Religion. Dia mengkhususkan diri dalam studi tradisi mistik Islam (tasawuf), pra-modern sejarah dunia Islam Kawasan Timur Tengah, dan pemikiran Islam pasca-modern, dan merupakan salah satu pendiri Uni Islam Progresif. Omid Safi memperoleh gelar Ph.D., di Duke University, dengan konsentrasi pada Islamic Studies. Selanjutnya memperoleh gelar M.A. History of Religions, dengan konsentrasi pada Islamic Studies. Sumber: http://id.shvoong.com/books/2247423-progressivemuslims-justice-gender-pluralism/\#ixzz2p2K8eYHK. Di akses tgl 2 Oktober 2019, pkl 15.00.
} 


\section{FARABI}

Jurnal Pemikiran Konstruktif Bidang Filsafat dan Dakwah

ISSN $1907-0993$

E ISSN $2442-8264$

Vol. 16 No. 2, Desember 2019

kadang bisa dipertukarkan. ${ }^{6}$

Gerakan dan pemikiran Islam progresif akan memperlihatkan bebagai penafsiran teologis berkaitan dengan problem-problem kontemporer terutama isu sekularisme, librelisme dan pluralisme. Dalam mengembangkan Islam progresif mereka melaukukan:

Pertama, pembaharuan pemahaman keislaman (khususnya fikih dan hukum Islam), terutama dalam rangka menyeleraskan pemahaman keagamaan dengan perkembangan kekinian. Mereka menyadari perlu adanya "fikih baru" yang mampu menjawab problem kemanusiaan dewasa ini. Misalnya umat Islam dituntut untuk mempertimbangkan fikih yang bisa berdialog dengan isu demokrasi (fikih demokrasi), pluralisme (fikih toleransi), libelarisme (fikih politik, fikih hak asasi manusia, fikih gender) dan seterusnya. ${ }^{7}$

Kedua, sosialisasi informasi yang benar tentang Islam. Belakangan ini, suara atas nama Islam dipresentasikan oleh kelompok-kelompok yang tidak mewakili sebagian besar umat Islam-yaitu kelompok yang sering disebut "Islam radikal”. Umat Islam secara keseluruhan mendapatkan stigma karena citra Islam radikal ini. Islam diidentikkan dengan seluruh tindakan yang bernuanasa kekerasan. Karena itulah pemikir Islam progresif ini bekerja keras menghadirkan wajah Islam Progresif--dalam arti Islam yang penuh kedamaian, toleran, moderat, bahkan liberal, santun, dan berkeadaban.

Di Indonesia bermunculan apa yang disebut Islam progresif abad ke-20 ${ }^{8}$ yakni ada dua kubu yang masing-masing memiliki peran fungsi yang sama, yang satu di wakili oleh pemikiran tradisional yaitu NU dan yang modern yaitu Muhammadiyah. Dalam perjalanan sejarahnya telah memunculkan gairah pemikiran baru melalui pembacaan kritis terhadap tradisi mereka sendiri: di Muhammadiyah mereka melakukan kritik terhadap bangunan nalar Muhammadiyah dan di NU juga melakukan kritik terhadap bangunan nalar NU.

\footnotetext{
${ }^{6}$ Ahmad Gaus AF, “Islam Progresif: Wacana Pasca Arus Utam”, Jurnal Tashwirul Afkar, Edisi No. 22 Tahun 2007, hlm. 96.

${ }^{7}$ Kehadiran fikih seperti ini menurut mereka sangat penting untuk membuktikan relevansi Islam dalam dunia yang lebih plural dan global apa yang disebut sholih likulli zaman.

${ }^{8}$ Mohammad Ali, Islam Muda Liberal, Post-Puritan, Post-Tradisional (Yogyakarta: Apeiron Philotes, 2006) hlm. 33.
} 


\section{FARABI}

Jurnal Pemikiran Konstruktif Bidang Filsafat dan Dakwah

ISSN $1907-0993$

E ISSN $2442-8264$

Vol. 16 No. 2, Desember 2019

Kritisisme mereka melampui teks. Mereka melakukan penafsiran bahkan dekontruksi pemikiran. Generasi baru yang kritis itu memunculkan kelompokkelompok progressif yang melahirkan pembaharuan-pembaharuan melalui sekelompok generasi 90-an. Secara umum kecenderungan ideologis mereka memang bersemangat kritis atas teks keagamaan, dekontruksionis, dan dalam batas-batas tertentu bercorak kekiri-kirian. ${ }^{9}$

\section{MUSLIM PROGRESIF DALAM PANDANGAN OMID SAFI}

Dalam pandangan Omid Safi istilah "Muslim progresif" berawal dari adanya serangkaian peristiwa yang terjadi di beberapa tempat yang berpenduduk Muslim seperti Palestina, Afganistan dan lainya yang menjadikan agama sebagai sarana untuk membakar emosi dan kemarahan massa guna meraih sesuatu yang sebenarnya di luar agama itu sendiri. Istilah Muslim progresif juga dilabelkan Safi kepada para pemikir agama yang selama ini belum banyak memberikan uraian tentang bagaimana memaknai agama Islam di era kontemporer di tengah-tengah multireligius dan multikultural. Bagaimana sesungguhnya memaknai Islam progresif tersebut? Bidang kajian apa saja yang dikategorikan Muslim progresif?

Omid Safi memandang rekonstruksi pemahaman agama yang dilakukan oleh kelompok Muslim progresif dipandang kapabel untuk memulai sebuah perubahan terhadap ketidakadilan, tindakan ahumanis, diskriminasi, dan pencemaran lingkungan yang terjadi saat ini, dengan mencontohkan prilaku para sufi, fuqaha, dan mutakallimin dalam mengimplementasikan visi keadilan, kebaikan, dan keindahan yang berdasarkan al-Quran.

Islam progresif adalah Islam yang menawarkan sebuah kontekstualisasi penafsiran Islam yang terbuka, ramah, segar, serta responsif terhadap persoalanpersoalan kemanusiaan. Menurut Omid Safi, Islam progresif menawarkan sebuah metode ber-Islam yang menekankan pada terciptanya keadilan sosial, kesetaraan gender, dan pluralisme keagamaan. Maka seorang Muslim yang progresif haruslah bersedia untuk berjuang demi menegakkan keadilan sosial di muka bumi ini. Perjuangan itu bisa berwujud pada advokasi hak-hak orang yang

\footnotetext{
${ }^{9}$ Nur Khalik Ridwan, Santri Baru, Pemetaan, Wacana Ideologi, dan Kritik (Yogyakarta: Gerigi Pustaka, 2004), hlm. 25.
} 


\section{FARABI}

Jurnal Pemikiran Konstruktif Bidang Filsafat dan Dakwah

ISSN $1907-0993$

E ISSN $2442-8264$

Vol. 16 No. 2, Desember 2019

termarjinalisasi, orang yang tertindas, orang yang terkena polusi lingkungan, serta orang yang "yatim" secara sosial dan politik.

Islam progresif meyakini bahwa semua pembelaan itu mempunyai dasar dan tradisi yang kuat dalam al-Quran dan Hadis. Banyak ayat-ayat al-Quran yang meneguhkan tentang pentingnya kepedulian sosial seperti yang tertera dalam surat al-Maun. Begitu juga, sejarah kehidupan dan dakwah Nabi tampak jelas membela hak-hak golongan mustadhafhin, fakir miskin, dan anak yatim. Dalam hal ini nampak bahwa yang menjadi ciri khas Islam progresif adalah pada aspek pembebasannya terhadap hak-hak kemanusiaan. Di samping itu, pemikiran progresif mempunyai gagasan maju, bukan hanya sikap terbuka saja. Maksudnya, ide-ide itu benar-benar berarti. Dalam hal ini cendekiawan berperan penting.

\section{Isu-isu Muslim Progresif}

Omid Safi menyebutkan beberapa isu penting yang harus dijawab oleh muslim progresif, antara lain adalah ketidakadilan gender, diskriminsasi terhadap kelompok minoritas baik minoritas agama ataupun etnis, pelanggaran hak asasi manusia, tidak adanya kebebasan berbicara, berkeyakinan dan mempraktikkan agama sendiri, pembagian kekayaan yang tidak merata, dan pemerintahan yang otoriter. $^{10}$

Pertama, Keadilan/gender, Muslim Progresif memulai dengan sikap sederhana namun radikal: komunitas Muslim secara keseluruhan tidak dapat mencapai keadilan kecuali keadilan dijamin bagi perempuan Muslim. Singkatnya, tidak ada interpretasi progresif Islam tanpa keadilan gender. Kesetaraan gender adalah tolok ukur keprihatinan lebih luas dari keadilan sosial dan pluralisme. ${ }^{11}$ Bahwa "gender" tidak hanya berbicara tentang perempuan. Terlalu sering Muslim lupa bahwa ketidakadilan gender bukan hanya sesuatu yang menindas perempuan, juga merendahkan dan dehumanisasi laki-laki Muslim yang berpartisipasi dalam sistem tersebut.

Secara jelas bahwa dengan "gender" kita tidak bermaksud untuk fokus secara eksklusif pada jilbab (penutup kepala yang dikenakan oleh beberapa

\footnotetext{
${ }^{10}$ Omid Safi, Progressive Muslims, hlm. 2-3

${ }^{11}$ W. Montgomery Watt, The Formative Period of Islamic Thought ( Oxford : Oneworld , 1998), hlm. 48.
} 


\section{FARABI}

Jurnal Pemikiran Konstruktif Bidang Filsafat dan Dakwah

ISSN $1907-0993$

E ISSN $2442-8264$

Vol. 16 No. 2, Desember 2019

perempuan Muslim). Jilbab, tidak diragukan lagi, salah satu penanda penting dari identitas bagi banyak perempuan Muslim yang memilih untuk memakai atau tidak memakainya. Ini juga merupakan penanda penting dari peraturan sosial ketika banyak wanita Muslim dipaksa untuk memakainya. Tapi itu sia-sia untuk terlibat dalam percakapan tentang gender yang mengurangi semua religiusitas perempuan dan eksistensi jilbab. Ada banyak isu yang lebih mendasar dipertaruhkan dalam konstruksi sosial yang mempengaruhi kehidupan pria dan wanita, dan kami bertujuan untuk terlibat didalamnya.

Beberapa esai dalam penyelidikan buku ini persis apa yang kita maksud dengan keadilan gender. Esai-esai oleh Sa'diyya Shaikh, Zoharah Simmons, Scott Kugle, dan Kecia Ali break new ground here. Feminisme Islam adalah gagasan radikal tentang 'perempuan Muslim adalah manusia penuh.' Manusia dan hak-hak agama untuk perempuan Muslim tidak dapat "diberikan," "diberikan kembali," atau "dipulihkan" karena mereka tidak pernah kita berikan - atau mengambil - di tempat yang pertama. Wanita Muslim memiliki hak yang diberikan Tuhan dengan kebajikan sederhana menjadi manusia. ${ }^{12}$

Keadilan gender sangat penting, sangat diperlukan, dan sangat penting. Dalam jangka panjang, interpretasi Muslim progresif akan dinilai oleh sejumlah perubahan dalam kesetaraan gender itu mampu menghasilkan pada komunitas kecil dan besar. Kesetaraan gender adalah tongkat pengukur dari keprihatinan yang lebih luas untuk keadilan sosial dan pluralisme. Penekanan pada isu-isu gender ini- dikarenakan muslim lebih suka mendorong dalam hal yang tertentu saja, atau setidaknya berurusan dalam batas-batas bahagia dan tidak bahagia dari komunitas mereka sendiri-akan menyerang yang lain sebagai sesuatu yang tidak seimbang. Meskipun disadaripembicaraan tentang gender itu menjadi dinamika kelompok politik di masyarakat Muslim. Tapi itu adalah cara masa lalu yang menyebalkan.

Tentu saja gerakan feminis di dunia Muslim telah menarik inspirasi sebagian besar dari sumber-sumber sekuler. Gerakan-gerakan ini telah membuka beberapa pintu, dan kita melihat guna membuka yang lain.Jika yang menyerang

\footnotetext{
${ }^{12}$ Ibid, hlm. 11.
} 


\section{FARABI}

Jurnal Pemikiran Konstruktif Bidang Filsafat dan Dakwah

ISSN $1907-0993$

E ISSN $2442-8264$

Vol. 16 No. 2, Desember 2019

beberapa orang sebagai oxymoron, secara tidak apologetik itu menunjukkan bahwa itu adalah definisi mereka tentang Islam yang memerlukan pemikiran ulang, bukan hubungan tentang Islam dan feminisme.

Kedua, diskriminasi terhadap kelompok minoritas, ini yang seharusnya kita perjuangkan dalam rangkat menegakkan keadilan serta kesetaraan bukan malah menjatuhkan satu dengan yang lainnya. Problem masyarakat sekarang adalah selalu membeda-bedakan atau mengclaster tidak saling menjaga dan saling melindungi. Padahal, Islam sendiri adalah agama yang menjunjung tinggi nilai keadilan, kesetaraan dan nilai-nilai luhur lainnya. Inilah yang disebut di dalam prinsip dasar Islam, yang oleh ulama terdahulu dikatakan sebagai tujuan syaria'ah (maqashid al-syari'ah).

Ketiga, HAM (Hak Asasi Manusia), dalam doktrin tradisional, bahwasanya hak asasi selalu menegaskan pertahanan terhadap pelanggaran atas kepentingan pribadi individu, khususnya yang di lakukan oleh negera. ${ }^{13}$ Gagasan hak asasi manusia di definisikan sebagai: ide bahwa ada hak-hak tertentu yang apakah diakui atau tidak, menjadi milik seluruh umat manusia sepanjang waktu dan sepanjang tempat. Ini adalah hak-hak yang mereka miliki hanya dalam sifat kemanusiaan yang melekat, terlepas dari nasionalitas, agama, seks, status social, jabatan, kekayaan, atau perbedaan karakteristik etnis, kultur atau social lainnya. ${ }^{14}$ Tidak ada demokrasi tanpa adanya hak asasi manusia, dan pada umumnya hak asasi manusia tidak dapat eksis tanpa adanya demokrasi. ${ }^{15}$

Sementara formulasi hak asasi manusia menurut Islam di definisikan dalam Cairo Declaration on Human Right in Islam yang di deklarasikan tanggal 15 Agustus 1990 di Kairo. Deklarasi ini terdiri dari 25 Pasal,yang meliputi: hakhak invidual, social, ekonomi, dan politik.

Hak-hak sipil dan politik meliputi hak persamaan dalam martabat manusia, kewajban dan tanggung jawab, hak persamaan di depan hokum, hak hidup yang

\footnotetext{
${ }^{13}$ Barry, Norman P. An Introduction to Modern Polical Theory, (New York: S Martin Pres, 1981), hlm. 181-183.

${ }^{14}$ Abdillah, Masykuri. Demokrasi di persimpangan Makna: Respon Intelektual Muslim Indonesia Terhadap Konsep Demokrasi, (Yogyakarta: Tiara Wacana, 1999), hlm. 94.

${ }^{15}$ Widjan, Aden dkk. Pemikiran dan Peradaban Islam, (Yogyakarta: Safrina Insania Press, 2007), hlm. 204.
} 


\section{FARABI}

Jurnal Pemikiran Konstruktif Bidang Filsafat dan Dakwah

ISSN $1907-0993$

E ISSN $2442-8264$

Vol. 16 No. 2, Desember 2019

merupakan pemberian/anugerah Tuhan, dan hak menyatakan pendapat secara bebas sejauh tidak bertentangan dengan syariat Islam.

Sedangkan hak-hak social ekonomi meliputi hak memperoleh pendidikan, hak bekerja, hak memiliki kekayaan, hak untuk memenuhi kebutuhan hidup yang memadai, hak untuk hidup aman bagi dirinya, agamanya, kehormatannya dan hartanya. ${ }^{16}$

\section{KARAKTERSTIK MUSLIM PROGRESIF}

Adapun mengenai Karakteristik menonjol yang dimiliki oleh pemikir muslim progresif, adalah:

Pertama, Mereka mengadopsi pandangan bahwa beberapa bidang hukum Islam tradisional membutuhkan perubahan dan reformasi substansial dalam rangka menyesuaikan dengan kebutuhan masyarakat muslim saat ini.

Kedua, Mereka cenderung mendukung akan perlunya fresh ijtihad (pemikiran yang segar) dan metodologi baru dalam ijtihad untuk menjawab permasalahan-permasalahan kontemporer.

Ketiga, Beberapa di antara mereka juga mengkombinasikan atau mengintegrasikan secara kreatif warisan kesarjanaan Islam tradisional dengan pemikiran dan pendidikan Barat modern.

Keempat, Mereka secara penuh optimis dan teguh berkeyakinan bahwa dinamika dan perubahan sosial, baik pada ranah intelektual, moral, hukum, ekonomi atau teknologi, dapat direfleksikan dalam hukum Islam.

Kelima, Mereka tidak merasa terikat pada dogmatisme atau mazhab hukum dan teologi tertentu dalam pendekatan kajiannya.

Keenam, Mereka lebih meletakkan titik tekan pemikirannya pada berbagai isu keadilan sosial, keadilan gender, HAM dan relasi yang harmonis antara Muslim dan non-Muslim. ${ }^{17}$

Lebih jauh dapat diuraikan sepuluh kriteria yang lebih bersifat teknis dari gerakan yang membedakan muslim progresif dengan lainnya, yaitu bahwa pemikiran muslim progresif memiliki pandangan dan keyakinan sebagai berikut:

\footnotetext{
${ }^{16}$ Ibid, hlm. 205.

${ }^{17}$ Abdullah Saeed, Islamic Thought An Introduction, (London and New York: Routledge, 2006), hlm. 150-151.
} 


\section{FARABI}

Jurnal Pemikiran Konstruktif Bidang Filsafat dan Dakwah

ISSN $1907-0993$

E ISSN $2442-8264$

Vol. 16 No. 2, Desember 2019

Pertama, Rasa nyaman (comfort) ketika menafsir ulang atau menerapkan kembali hukum dan prinsip-prinsip dasar Islam. Kedua, Bahwa keadilan gender adalah ditegaskan dalam Islam. Ketiga, Bahwa semua agama secara inheren adalah sama dan harus dilindungi secara konstitusional. Keempat, bahwa semua manusia juga setara dan sama; kelima, bahwa keindahan merupakan bagian inheren dari tradisi Islam baik yang ditemukan dalam seni, arsitektur, puisi maupun musik. Keenam, dukungan atas kebebasan berbicara, berkeyakinan dan berserikat. Ketujuh, menunjukkan kasih sayang pada semua makhluk. Kedelapan, anggapan bahwa hak "orang lain" itu ada dan perlu dihargai. Kesembilan, sikap moderat dan antikekerasan dalam menyelesaikan permasalahan masyarakatnya. Kesepuluh, kesukaan dan antusiasnya ketika mendiskusikan isu-isu yang berkaitan dengan peran agama dalam tataran publik. ${ }^{18}$

\section{E. PEMIKIR-PEMIKIR MUSLIM PROGRESIF}

Pemikir-pemikir muslim progresif pada masa kini tersebar di berbagai negara. Di antara mereka yang bisa disebutkan di sini adalah Abdul Karim Soroush (Iran), Shirin Ebadi (Iran), Muhammad Shahrur (Suriah), Muhammad Habash (Suriah), Muhammad al-Talibi (Tunisia/Perancis), Fathullah Gülen (Turki/USA) dan Farish A Noor. Soroush berusaha membangun demokrasi di Iran yang disebutnya dengan "demokrasi relijius" yang merupakan respons terhadap sistem politik ala velayat-e faqih. Menurutnya, demokrasi merupakan buah dari pemikiran manusia yang didasarkan atas pemahaman-pemahaman rasional yang memuat nilai keadilan dan konsep-konsep hak asasi manusia.

Karena itu, nilai-nilai demokratis harus diejawentahkan oleh umat Islam dalam menjalankan pemerintahan. Sistem politik tirani, baginya, bertentangan dengan hakekat dan martabat kemanusiaan. Lebih lanjut dia menegaskan bahwa demokrasi tidak berarti memisahkan agama dari dunia poltik. Demokrasi justru dapat menjaga eksistensi dan ruang gerak agama. Umat dan lembaga-lembaga

\footnotetext{
${ }^{18}$ IDSS, "Progressive Islam," hlm. 5; Bandingkan dengan lima kriteria yang dikemukakan olch Omid Safi, yaitu: berkehendak untuk melawan ketidakadilan pada masyarakat di mana muslim berada, menyadari bahwa tidak semua yang datang dari Barat itu pasti benar dan menguntungkan, mendukung pluralisme, Lihat, Omid Safi, Progressive Muslims, hlm. 9-15; lihat pula Omid Safi, "What is Progressive Islam," dalam The International Institute for the Study of Islam in the Modern World (ISIM) News Letter, No.13, Desember 2003, hlm. 10.
} 


\section{FARABI}

Jurnal Pemikiran Konstruktif Bidang Filsafat dan Dakwah

ISSN $1907-0993$

E ISSN $2442-8264$

Vol. 16 No. 2, Desember 2019

keagamaman seharusnya terpanggil untuk terlibat dalam diskursus-diskursus politik, sehingga nilai-nilai relijius dapat mempengaruhi gerak dan langkah manusia dalam berpolitik. Meskipun demikian, pandangan-pandangan keagamaan tidak boleh didikte oleh Negara dan tidak boleh dilaksanakan dengan cara pemaksaan. Nilai-nilai keagaman harus diperjuangkan dan dibawa oleh masyarakat sendiri dalam diskursus-diskursus politik dan sosial.

Di antara pemikir Muslim Progresif Farish A. Noor dan Omid Safi secara singkat memberikan ciri-ciri dari kelompok Islam progresif, yaitu: mereka yang cukup kritis terhadap fenomena ketidakadilan, baik dalam perspektif lokal maupun nasional dan global.

Mereka memiliki concern untuk menegakkan keadilan di wilayah di mana mereka hidup dan bertempat tinggal. Sebagai dasar dari kritisime dan konsern di atas, mereka juga kritis terhadap medernisme atau fenomena modernisasi pada umumnya. Mereka cenderung mengapresiasi dan bahkan menggunakan pos modernisme sebagai alat analisis dan kesadaran dalam melihat fenomena perubahan. Ciri lainnya adalah memiliki kepedulian sebagai titik tolak dan sekaligus kritis terhadap tradisi Islam yang panjang.

Mereka teguh memegangi keyakinan Islam dan memberikan apresiasi terhadap seluruh warisan dan tradisi Islam, tetapi dalam waktu yang sama mereka juga kritis terhadapnya ketika mereka dihadapkan dengan fenomena perubahan. Dan ciri penting berikutnya adalah: mereka tidak hanya bertengger di menara gading sebagai intelektual tetapi juga ikut terjun langsung dalam proses penyadaran dan menggerakkan masyarakat.

Muslim progresif mengkaji sumber-sumber tekstual dan bahan-bahan tradisi Islam, menginterpretasikannya, selanjutnya mengaitkan tradisi lama dengan era kontemporer. Menurut Mohammed Arkoun, mengaitkan antara tradisi dan modernitas serta menyikapi keduanya dengan adil dan bijaksana adalah baik. Namun keterlibatan mereka dalam merekonstruksi, mengevaluasi, dan merevivalisai tradisi kadang-kadang menginspirasikan, membosankan, dan bahkan terasa sakit. Hal ini wajar saja terjadi karena tradisi adalah milik orang di masa lampau dan modernitas adalah milik Barat. Oleh karenanya kita harus 


\section{FARABI}

Jurnal Pemikiran Konstruktif Bidang Filsafat dan Dakwah

ISSN $1907-0993$

E ISSN $2442-8264$

Vol. 16 No. 2, Desember 2019

mengharmonisasikannya untuk bisa menjadikan pemahaman umat Islam di era kontemporer lebih progresif.

\section{F. PENUTUP}

Dari paparan di atas dapat diambil kesimpulan bahwa Islam Progresif atau subjeknya Muslim Progressif berupaya untuk mengaktifkan kembali dimensi progresif Islam yang dalam kurun waktu cukup lama mati suri terpenjara oleh dominasi teks.

Munculnya tradisi Muslim Progresif diharapkan akan membawa dampak positif pada perkembangan masyarakat Islam untuk terus bergulat dalam perdebatan kontemporer yang tidak lagi mempermasalahkan soal "wadah" atau bentuk pergerakan dalam pergerakan Islam termasuk Islam Indonesia. Wadah atau format adalah perdebatan masa lalu sekarang harus sudah menuju pada artikulasi yang genuine tentang gerakan mendorong pada tradisi kemanusiaan dan peradaban yang lebih maju dan demokratis.

\section{DAFTAR PUSTAKA}

Abdullah Saeed, Islamic Thought An Introduction, London and New York: Routledge, 2006

Abdillah, Masykuri. Demokrasi di persimpangan Makna: Respon Intelektual Muslim Indonesia Terhadap Konsep Demokrasi, Yogyakarta: Tiara Wacana, 1999

Ahmad Gaus AF, "Islam Progresif: Wacana Pasca Arus Utam", Jurnal Tashwirul Afkar, Edisi No. 22 Tahun 2007

Mohammad Ali, Islam Muda Liberal, Post-Puritan, Post-Tradisional Yogyakarta: Apeiron Philotes, 2006

Noor, Farish A. Islam Progresif: Peluang, Tantangan, dan Masa Depannya di Asia Tenggara. Terj. Moch. Nur Ichwan dan Imron Rosyadi. Yogyakarta: SAMHA, 2006

Nur Khalik Ridwan, Santri Baru, Pemetaan, Wacana Ideologi, dan Kritik, Yogyakarta: Gerigi Pustaka, 2004 


\section{FARABI}

Jurnal Pemikiran Konstruktif Bidang Filsafat dan Dakwah

ISSN $1907-0993$

E ISSN $2442-8264$

Vol. 16 No. 2, Desember 2019

Omid Safi (ed), Progresive Muslims; On Justice Gender and Pluralism, England: Oneworld Oxford, 2005 , "What is Progresive Islam, dalam The International Institute for the Study of Islam in the Modern World (ISIM) News Letter, No.13, Desember 2003

W. Montgomery Watt, The Formative Period of Islamic Thought Oxford : Oneworld , 1998

Wahyudi, Yudian. Maqashid Syari'ah dalam Pergumulan Politik. Yogyakarta: Nawesea, 2006

Widjan, Aden dkk. Pemikiran dan Peradaban Islam, Yogyakarta: Safrina Insania Press, 2007

IDSS, "Progressive Islam and The State in Contemporary Muslim Societies," Laporan Seminar yang diadakan di Marina Mandarin Singapore tanggal 78 Maret 2006. 